\title{
Consensus Mapping and Identification of Markers for Marker-Assisted Selection of Wsm2 in Wheat
}

\author{
Huangjun Lu, Rebecca Kottke, Ravindra Devkota, Paul St. Amand, Amy Bernardo, Guihua Bai,

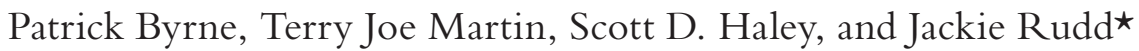

\begin{abstract}
A recently identified Wheat streak mosaic virus (WSMV) resistance gene Wsm2 confers a high level of resistance. Objective of this study was to identify closely linked DNA markers for Wsm2 for use in marker-assisted selection (MAS) in wheat (Triticum aestivum L.). Two segregating populations (CO960293-2 × 'TAM 111' and CO960293-2 $\times$ 'Yuma') of $F_{2: 3}$ families were evaluated for response to WSMV infection in growth chamber experiments. Forty-eight simple sequence repeat (SSR) or sequence-tagged site (STS) markers were screened for polymorphism between the parents of both populations. In the C0960293-2 $\times$ TAM 111 population, five markers were mapped to the region of Wsm2 with XSTS3B-55 being the closest marker (5.2 cM distal to Wsm2). In the C0960293-2 × Yuma population, eight markers were linked to Wsm2 with the closest marker Xbarc102 linked at $3.9 \mathrm{cM}$ proximal to $W s m 2$. Results from consensus mapping of the two populations suggested that Xbarc102 was distal to Wsm2. The marker Xbarc102 was associated with Wsm2 in all 22 wheat lines derived from crosses between susceptible parents and either C0960293-2 or 'RonL' (also carrying Wsm2). The marker allele Xbarc102-219-bp present in C0960293-2 was amplified in polymerase chain reaction (PCR) from Wsm2-carrying genotypes C0960293-w133, RonL, and 'Snowmass' but not from the resistant line KS96HW10-3 (carrying Wsm1) or the susceptible genotypes 'Karl 92', 'TAM 107', and 'N96L9970'. Therefore, this marker should be useful for MAS of Wsm2 in breeding programs.
\end{abstract}

H. Lu, R. Devkota, and J. Rudd, Texas AgriLife Research and Extension Center at Amarillo, 6500 Amarillo Blvd, West, Amarillo, TX 79106; R. Kottke, P. Byrne, and S.D. Haley, Dep. of Soil and Crop Sciences, Colorado State Univ., Fort Collins, CO 80523; P.S. Amand and G. Bai, USDA-ARS, Hard Winter Wheat Genetics Unit, 4008 Throckmorton Hall, Kansas State University, Manhattan, KS 66506; A. Bernardo, Department of Plant Pathology, 4024 Throckmorton Hall, Kansas State University, Manhattan, KS 66506; T.J. Martin, KSU Ag Research Center-Hays, 1232 240th Ave., Hays, KS 67601; H. Lu (present address): Everglades Research and Education Center, IFAS, University of Florida, 3200 E. Palm Beach Rd., Belle Glade, FL 33430. Received 18 July 2011. `Corresponding author (jcrudd@ag.tamu.edu).

Abbreviations: DPI, days post inoculation; FHB, Fusarium head blight; LOD, logarithm of the odds; MAS, marker-assisted selection; PCR, polymerase chain reaction; QTL, quantitative trait loci/locus; RH, relative humidity; SSR, simple sequence repeat; STS, sequencetagged site; WSMV, Wheat streak mosaic virus.

$\mathrm{W}$ HEAT STREAK MOSAIC VIRUS (WSMV) belongs to the genus Tritimovirus and is found in most wheat (Triticum aestivum L.) growing regions in the world. The virus, transmitted by the wheat curl mite (Aceria tosichella Keifer) is a serious pathogen of wheat, especially winter wheat, in the Great Plains of North America (French and Stenger, 2003). Typical symptoms caused by WSMV on wheat are a chlorotic, streaking mosaic. Yield loss estimates specific to WSMV in the region range from 2.6 (Christian and Willis, 1993) to 5\% (French and Stenger, 2003), although local disease outbreaks can result in total crop failure.

Wsm1 has been reported to confer resistance to WSMV (Friebe et al., 1991) and has been used for improvement of wheat (Baley et al., 2001; Graybosch et al., 2009; Sharp et al., 2002). It originated

Published in Crop Sci. 52 (2012).

doi: 10.2135/cropsci2011.07.0363

Published online 2 Dec. 2011.

(C) Crop Science Society of America | 5585 Guilford Rd., Madison, WI 53711 USA

All rights reserved. No part of this periodical may be reproduced or transmitted in any form or by any means, electronic or mechanical, including photocopying, recording, or any information storage and retrieval system, without permission in writing from the publisher. Permission for printing and for reprinting the material contained herein has been obtained by the publisher. 
from intermediate wheatgrass [Thinopyrum intermedium (Host) Backworth \& D. R. Dewey] and was transferred to wheat via a compensating Robertsonian translocation, where the short arm of wheat chromosome 4D was replaced by the short arm of the intermediate wheatgrass chromosome 4Ai\#2, forming T4DL.4Ai\#2S (Friebe et al., 1991; Wells et al., 1973, 1982). Wsm1 is a temperature-sensitive gene, conferring a high level of resistance up to $18^{\circ} \mathrm{C}$ but being ineffective at $24^{\circ} \mathrm{C}$ (Seifers et al., 1995). Because of the large fragment of an alien chromosome in the wheat background, the T4DL.4Ai\#2S translocation has deleterious effects on yield and bread-making quality (Seifers et al., 1995), which limits its application in wheat improvement. Efforts have been made to reduce the size of the alien chromosomal fragment while retaining the $W_{s m} 1$ gene in wheat (Friebe et al., 2009). More recently, CO960293-2, a winter wheat germplasm line developed by Colorado State University in Fort Collins, CO, was identified to have a high level of resistance to WSMV (Haley et al., 2002; Seifers et al., 2006). Genetic study and mapping work showed that the resistance in CO960293-2 was controlled by a single dominant gene different from Wsm1. This newly identified gene has been designated as Wsm2 and located to chromosome 3BS (Lu et al., 2011). Wsm2 is flanked by two simple sequence repeat (SSR) markers Xgwm389 and Xgwm566 at a $76.2 \mathrm{cM}$ interval, but these flanking markers are too far from the gene and therefore are not useful for markerassisted selection (MAS). Like Wsm1, Wsm2 functions as a temperature-sensitive gene, effective against WSMV at $19^{\circ} \mathrm{C}$ or below (Lu et al., 2011; Seifers et al., 2006) but ineffective at $24^{\circ} \mathrm{C}$ (Seifers et al., 2006).

Wsm2 has been recently incorporated into the cultivars RonL (PI 648020; Seifers et al., 2007) and Snowmass (PI 658597; Haley et al., 2011). Wsm2 appears to have originated from common wheat, and there is no evidence of deleterious impacts on yield and agronomic traits such as has been found with Wsm1. Identification of markers that are tightly linked to $W_{s m} 2$ will facilitate MAS to accelerate the transfer of Wsm2 to improved wheat cultivars. This study was designed to (i) develop a saturated map in the 3BS chromosome region containing Wsm2, (ii) identify the closely linked markers to $W_{s m} 2$ for MAS, and (iii) validate the newly identified markers in selected advanced wheat breeding lines.

\section{MATERIALS AND METHODS}

\section{Plant Materials}

The population CO960293-2 × 'TAM 111' (PI 631352; Lazar et al., 2004) consisting of $188 \mathrm{~F}_{2: 3}$ families was previously used for mapping of WSMV resistance gene in CO960293-2, which resulted in identification of $W_{s m} 2$ and locating it to chromosome 3BS (Lu et al., 2011). TAM 111 is moderately susceptible and clearly distinguishable for its reaction to WSMV infection from CO960293-2. In the present study, the same population was used for saturation mapping of the Wsm2 region. Another population of $142 \mathrm{~F}_{2: 3}$ families was developed from the cross of CO960293-2 × 'Yuma' (PI 559720) to verify the gene and the linked markers. Yuma is susceptible to WSMV. Molecular mapping in the CO960293-2 $\times$ TAM 111 population was conducted in Amarillo, TX, and the CO960293-2 $\times$ Yuma population was done in Fort Collins, CO.

Twenty-eight additional advanced breeding lines or wheat genotypes were used to validate the markers closely linked to Wsm2 (Table 1). Among these, the WSMV resistant line KS96HW10-3 carries Wsm1 (Seifers et al., 1995) while 'Karl 92', 'N96L9970', and 'TAM 107' are susceptible to WSMV. CO960293-w133 is a reselection of CO960293 (the line from which CO960293-2 was selected) and presumably contains Wsm2 (T.J. Martin, unpublished data, 2010). The remaining 22 lines were advanced breeding lines containing either CO960293-2 or RonL in their pedigrees.

\section{Inoculum Preparation}

Wheat streak mosaic virus inoculum used in this study was the isolate Sidney 81, courtesy of Dr. D. Seifers (Kansas State University, Hays, KS). Preparation of the inoculum for screening the CO960293-2 $\times$ TAM 111 population and for use in validation of markers in Texas was described previously ( $\mathrm{Lu}$ et al., 2011). Briefly, the leaf tissue was blended in a blender with 0.1 $\mathrm{M}$ potassium phosphate buffer ( $\mathrm{pH} 7.4$ ), filtered with cheesecloth, and mixed with silicon carbide powder. The prepared inoculum was used for mechanical inoculation of the Karl 92 wheat plants at two- to three-leaf stage using a spray paint gun. The infected plants were kept in a greenhouse for 2 wk and the plants showing symptoms were harvested for preparation of the inoculum for screening the population and for use in marker validation. The infected tissue was first tested by polymerase chain reaction (PCR) to confirm single infection of WSMV as described in $\mathrm{Lu}$ et al. (2011). Then $40 \mathrm{~g}$ of infected tissue were blended in a blender with $1 \mathrm{~L}$ of $0.1 \mathrm{M}$ potassium phosphate buffer ( $\mathrm{pH}$ 7.4), filtered with four layers of cheesecloth, and mixed with silicon carbide powder. The inoculum for screening the CO960293-2 $\times$ Yuma population in Colorado was prepared by propagating virus in 'Ankor' wheat (PI 632275; Haley et al., 2004). Briefly, isolate Sidney 81 was blended in a blender at a 1:10 (w/v) dilution in $0.02 \mathrm{M}$ potassium phosphate buffer ( $\mathrm{pH}$ 7.4), filtered through cheesecloth, and mixed with silicon carbide powder. The Ankor plants were mechanically inoculated at the one- to two-leaf stage with Sidney 81 inoculum using the finger-rub inoculation method (Seifers, 1992). Plants were kept in a growth chamber at $21^{\circ} \mathrm{C}$ with $12-\mathrm{h}$ daylength. Symptomatic tissues were harvested at $28 \mathrm{~d}$ post inoculation (DPI) and frozen at $-80^{\circ} \mathrm{C}$ until use. The tissues were tested by indirect enzyme-linked immunosorbent assay (ELISA) against Triticum mosaic virus and WSMV antiserum to confirm infection with WSMV using the procedure in Seifers et al. (2008). Inoculum was prepared from the thawed tissues of infected Ankor plants as described above and was applied to plants of the CO960293-2 × Yuma population using the finger-rub method.

\section{Wheat Streak Mosaic Virus Screening}

To screen the CO960293-2 × TAM 111 population, five seeds of each $\mathrm{F}_{2: 3}$ family, the parents, resistant checks KS96HW10-3 


\begin{tabular}{|c|c|c|c|c|c|c|}
\hline Line or cultivar & Pedigree & $\begin{array}{l}\text { Response } \\
\text { to WSMV } \\
\text { infection }^{\dagger}\end{array}$ & $\begin{array}{l}\text { Xbarc102 } \\
219 \mathrm{bp} \\
(\mathrm{VIC})^{\ddagger}\end{array}$ & $\begin{array}{l}\text { Xbarc87 } \\
119 \text { bp } \\
\text { (FAM) }\end{array}$ & $\begin{array}{l}\text { Xgwm493 } \\
214 \text { bp } \\
\text { (NED) }\end{array}$ & Reference \\
\hline C0960293-2 & PI 222668/TAM 107//C0850034 & $\mathrm{R}$ & + & + & + & Haley et al., 2002 \\
\hline C0960293-w133 & PI 222668/TAM 107//CO850034 & $\mathrm{R}$ & + & + & - & $\begin{array}{l}\text { T.J. Martin, unpublished } \\
\text { data, } 2010\end{array}$ \\
\hline Snowmass & KS96HW94//Trego/C0960293-2 & $\mathrm{R}$ & + & + & + & Haley et al., 2011 \\
\hline $\begin{array}{l}\text { KS96HW10-3 } \\
\text { (Wsm1) }\end{array}$ & KS97HW29/KS97HW131//KS96HW100-5 & $\mathrm{R}$ & - & + & - & Seifers et al., 2003 \\
\hline Karl 92 & $\begin{array}{l}\text { Plainsman VV3/Kaw/Atlas } \\
\text { 50V//Parker/Agent }\end{array}$ & S & - & + & - & Sears et al., 1997 \\
\hline N96L9970 & GRS1201/TAM 202 & $S$ & - & - & - & Graybosch et al., 2004 \\
\hline TAM 107 & TAM 105*4/Amigo & S & - & - & - & Porter et al., 1987 \\
\hline 7001 & $\begin{array}{l}\text { KSO25580(TREGO/CO960293-2)/KSO2HW119 } \\
\text { (95HW431(RB/89H33)/JGR8W//LAKIN SIB) }\end{array}$ & $\mathrm{R}$ & + & + & + & T.J. Martin, this study \\
\hline 7004 & $\begin{array}{l}\text { KS025580(TREGO/CO960293-2)/KS02HW25 } \\
\text { (TGO/JGR 8W) }\end{array}$ & $\mathrm{R}$ & + & + & + & T.J. Martin, this study \\
\hline 7007 & $\begin{array}{l}\text { KS025597(TREGO/CO960293-2)//KSOOHW152-1- } \\
\text { 4(94H871//VTA/94HW301)/KSO2HW174 } \\
\text { (FIDEL/KS97HW153//KS97HW349) }\end{array}$ & $\mathrm{R}$ & + & + & + & T.J. Martin, this study \\
\hline 7010 & $\begin{array}{l}\text { KS025597(TREGO/CO960293-2)//KSOOHW152- } \\
\text { 1-4(94H871//VTA/94HW301)/KSO2HW174(FIDEL/ } \\
\text { KS97HW153//KS97HW349) }\end{array}$ & $\mathrm{R}$ & + & + & + & T.J. Martin, this study \\
\hline 7019 & $\begin{array}{l}\text { KS03HW154(TREGO/CO960293-2)/KS03HW1(FIDE } \\
\text { L/97HW150//97HW349/3/TGO) }\end{array}$ & $\mathrm{R}$ & + & + & + & T.J. Martin, this study \\
\hline 7022 & $\begin{array}{l}\text { KS03HW154(TREGO/CO960293-2)/KS03HW1(FIDE } \\
\text { L/97HW150//97HW349/3/TGO) }\end{array}$ & $\mathrm{R}$ & + & + & + & T.J. Martin, this study \\
\hline 7025 & $\begin{array}{l}\text { KS03HW154(TREGO/CO960293-2)/KS03HW1(FIDE } \\
\text { L/97HW150//97HW349/3/TGO) }\end{array}$ & $\mathrm{R}$ & + & + & + & T.J. Martin, this study \\
\hline 7028 & DANBY/KS03HW149-1(TREGO/CO960293-2) & $\mathrm{R}$ & + & + & + & T.J. Martin, this study \\
\hline 7031 & DANBY/KS03HW149-1(TREGO/CO960293-2) & $\mathrm{R}$ & + & + & - & T.J. Martin, this study \\
\hline 7046 & $\begin{array}{l}\text { JAGALENE/KS01HW163-4(TREGO/BTY SIB)// } \\
\text { KS03HW149(TREGO/CO960293-2) }\end{array}$ & $\mathrm{R}$ & + & + & - & T.J. Martin, this study \\
\hline 6030 & $\begin{array}{l}\text { 04-5421(99-5011/3/FIDEL/KS97HW153// } \\
\text { KS97HW349)//KSO3HW157-4(TREGO/CO960293- } \\
\text { 2)/KS02HW118-1(95HW431/JGR8W//TREGO) }\end{array}$ & $\mathrm{R}$ & + & + & + & T.J. Martin, this study \\
\hline 5141 & $\begin{array}{l}\text { KS04HW101-3(98HW423(JGR/93HW242)/98HW170 } \\
\text { (ARL/WGRC15))/RonL }\end{array}$ & $\mathrm{R}$ & + & + & + & T.J. Martin, this study \\
\hline 5147 & $\begin{array}{l}\text { KSO4HW101-3(98HW423(JGR/93HW242)/98HW170 } \\
\text { (ARL/WGRC15))/RonL }\end{array}$ & $\mathrm{R}$ & + & + & + & T.J. Martin, this study \\
\hline Co07W380 & Burchett/CO960293-2//Stanton & $R$ & + & + & + & S.D. Haley, this study \\
\hline C007W607 & JAGALENE/KS03HW149-1 (TREGO/CO960293-2) & $\mathrm{R}$ & + & + & + & S.D. Haley, this study \\
\hline C007W614 & $\begin{array}{l}\text { JAGALENE/KS03HW122 (LAKIN/ } \\
\text { TGO//96HW71)//03-6149 (TREGO/C0960293-2) }\end{array}$ & $\mathrm{R}$ & + & + & + & S.D. Haley, this study \\
\hline CO07W607-F1 & JAGALENE/KS03HW149-1 (TREGO/CO960293-2) & $\mathrm{R}$ & + & + & + & S.D. Haley, this study \\
\hline CO07W607-F2 & JAGALENE/KS03HW149-1 (TREGO/CO960293-2) & $\mathrm{R}$ & + & + & + & S.D. Haley, this study \\
\hline 6029 & $\begin{array}{l}\text { 04-5421 (99-5011/3/FIDEL/KS97HW153// } \\
\text { KS97HW349)//KSO3HW157-4 (TREGO/CO960293- } \\
\text { 2)/KS02HW118-1 (95HW431/JGR8W//TREGO) }\end{array}$ & S & - & - & - & T.J. Martin, this study \\
\hline 5143 & $\begin{array}{l}\text { KS04HW101-3 (98HW423(JGR/93HW242)/ } \\
\text { 98HW170 (ARL/WGRC15))/RonL }\end{array}$ & $S$ & - & + & - & T.J. Martin, this study \\
\hline 5148 & $\begin{array}{l}\text { KSO4HW101-3 (98HW423(JGR/93HW242)/98HW17 } \\
\text { O(ARL/WGRC15))/RonL }\end{array}$ & $S$ & - & + & - & T.J. Martin, this study \\
\hline 5150 & $\begin{array}{l}\text { KS04HW101-3(98HW423(JGR/93HW242)/98HW170 } \\
\text { (ARL/WGRC15))/RonL }\end{array}$ & $S$ & - & + & - & T.J. Martin, this study \\
\hline
\end{tabular}

${ }^{\dagger} \mathrm{R}$, resistance to Wheat streak mosaic virus (WSMV); S, susceptibility to WSMV.

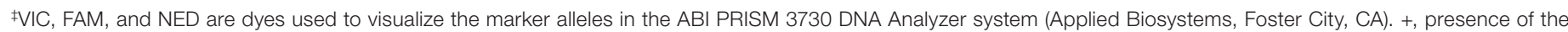
marker allele; -, absence of the marker allele.

and 'Mace' (both carrying Wsm1), susceptible check Karl 92, and the Texas cultivar TAM 112 (PI 643143) were germinated in half of the $30-\mathrm{cm}$ row in $30 \times 50 \mathrm{~cm}$ plastic flats with 11 rows per flat. The families along with the six genotypes were grown in flats with a RCBD with two replications. The experiments were performed twice with a total of 20 seeds grown per $\mathrm{F}_{3}$ family. The flats were placed in a greenhouse at Texas AgriLife Research, Bushland, TX. At the two- to three-leaf 
stage, the plants were mechanically inoculated with inoculum using a spray paint gun at $4 \mathrm{~kg} \mathrm{~cm}^{-1}$. The flats were moved into a growth chamber and kept at $19^{\circ} \mathrm{C}$ day time, $17^{\circ} \mathrm{C}$ night time, $15 \mathrm{~h}$ daylength, and 40\% relative humidity (RH). Each plant was scored as resistant or susceptible at 28 DPI using the method described in Lu et al. (2011).

For screening the CO960293-2 $\times$ Yuma population, each $\mathrm{F}_{2: 3}$ family, parents, resistant controls RonL (Wsm2) and KS96HW10-3 (Wsm1), and susceptible controls 'Tomahawk' (PI 552814) and Ankor were planted in 30 by $50 \mathrm{~cm}$ plastic flats. Twelve seeds of each family and control were sown in each row with 12 rows per flat. The experiment was arranged in a RCBD design with two replications. Flats were held in growth chambers at $17^{\circ} \mathrm{C}$ with 12 $\mathrm{h}$ daylength and 40\% RH at Colorado State University in Fort Collins, CO. At the one- to two-leaf stage, plants were inoculated with WSMV inoculum using the finger-rub method described in Seifers (1992). Plants were scored as resistant or susceptible at 28 DPI using the rating scales in Lu et al. (2011).

In the marker validation experiment, 10 seeds per entry (Table 1) were germinated in a $30-\mathrm{cm}$ row in 30 by 50 plastic flats. Each flat held 11 rows. The experiment was conducted using a RCBD design with three replications. Therefore, a total of 30 seeds of each line or cultivar were tested. Flats were placed in a greenhouse at Texas AgriLife Research, Bushland, TX. At the two- to three-leaf stage, plants were mechanically inoculated using a spray paint gun at $4 \mathrm{~kg} \mathrm{~cm}^{-1}$. The flats were moved to a growth chamber with the environmental conditions the same as those used in Lu et al. (2011).

\section{Molecular Marker Analysis}

Deoxyribonucleic acid extraction of the CO960293-2 × TAM 111 population was described previously ( $\mathrm{Lu}$ et al., 2011). For the CO960293-2 $\times$ Yuma population, leaf tissues were collected from each $\mathrm{F}_{2}$ plant used to develop the $\mathrm{F}_{2: 3}$ families. Approximately $10 \mathrm{~cm}$ of leaf tissue from each $\mathrm{F}_{2}$ individual was placed into a single well in a 96-deep-well plate. Tissues were lyophilized for approximately $48 \mathrm{~h}$ and ground to a fine powder using a $4.5 \mathrm{~mm}$ steel bead with $2 \mathrm{~min}$ of agitation at 30 cycles per sec on a Mini Bead-Beater (Biospec Products, Bartlesville, OK). Total genomic DNA was extracted from the ground tissues using a sodium dodecyl sulfate (SDS)-based DNA extraction procedure (KS-USDA Genotyping Laboratory, Manhattan, KS). The DNA pellets were resuspended in $200 \mu \mathrm{L}$ autoclaved double distilled $\mathrm{H}_{2} \mathrm{O}$ and allowed to sit at $4^{\circ} \mathrm{C}$ overnight. The DNA concentrations were adjusted to $100 \mathrm{ng} \mu \mathrm{L}^{-1}$ for use in PCR. For marker validation, $1 \mathrm{~cm}$ of leaf tissue was cut from each of 10 seedlings of each cultivar and advanced breeding line at the two-leaf stage. Leaf tissues from the 10 seedlings were bulked and placed into a single well of a 96-deep-well plate. Deoxyribonucleic acid was extracted as described in Lu et al. (2011) and diluted to $100 \mathrm{ng}$ $\mu \mathrm{L}^{-1}$ with sterile water.

Bulked segregant analysis (Michelmore et al., 1991) was conducted in both populations. The WSMV-resistant bulk samples were produced by pooling equal amounts of DNA from five to six $\mathrm{F}_{2}$ plants whose $\mathrm{F}_{3}$ families were homozygous resistant for WSMV while equal amount of DNA from five to six $\mathrm{F}_{2}$ plants producing homozygous susceptible $\mathrm{F}_{3}$ families were pooled to form the WSMV-susceptible bulk samples. Simple sequence repeat and sequence-tagged site (STS) markers between the flanking SSR markers Xgwm389 and Xgwm566 were selected for screening the parents and the bulks for polymorphism. A total of 48 SSR and STS markers (Supplemental Table S1) were tested. The primers information was obtained from the USDA website (USDA-ARS, 2010) and primers were commercially synthesized. Each $10 \mu \mathrm{L}$ PCR reaction contained 1x PCR buffer, $2.5 \mathrm{mM} \mathrm{MgCl}_{2}, 0.2 \mathrm{mM}$ deoxyribonucleotide triphosphate (dNTP) mix, $200 \mathrm{nM}$ reverse primer, 100 nM of M13-tailed forward primer, 1U Taq DNA polymerase, 100 ng template DNA, and $100 \mathrm{nM}$ of M13 primers labeled with one of the following dyes: 6-FAM, NED, PET, or VIC (Applied Biosystems, Foster City, CA). Reactions were performed in a PTC100 MJ Thermal Cycler (MJ Research, Watertown, MA) with a touchdown program starting with $5 \mathrm{~min}$ at $95^{\circ} \mathrm{C}$; five cycles of 1 $\min$ at $96^{\circ} \mathrm{C}, 5 \mathrm{~min}$ at $68^{\circ} \mathrm{C}$ with the annealing temperature being decreased by $2^{\circ} \mathrm{C}$ per cycle, and $1 \mathrm{~min}$ at $72^{\circ} \mathrm{C}$; followed by five cycles of $1 \mathrm{~min}$ at $96^{\circ} \mathrm{C}, 2 \mathrm{~min}$ at $58^{\circ} \mathrm{C}$ with annealing temperature decreased by $2^{\circ} \mathrm{C}$ per cycle, and $1 \mathrm{~min}$ at $72^{\circ} \mathrm{C}$; and then 25 cycles of $1 \mathrm{~min}$ at $96^{\circ} \mathrm{C}, 1 \mathrm{~min}$ at $50^{\circ} \mathrm{C}$, and $1 \mathrm{~min}$ at $72^{\circ} \mathrm{C}$ with a final extension of $5 \mathrm{~min}$ at $72^{\circ} \mathrm{C}$. Three microliters of the PCR products labeled with four different fluorescent dyes were pooled together with formamide plus GeneScan500 LIZ sizing standard (Applied Biosystems, Foster City, CA) and analyzed on an ABI PRISM 3730 DNA Analyzer (Applied Biosystems).

\section{Data Analysis}

Data files obtained from the ABI PRISM 3730 DNA Analyzer were analyzed with GeneMarker version 1.6 (SoftGenetics, 2010) and rechecked manually for accuracy. Individual linkage groups from the two populations and the consensus map were constructed with JoinMap 3.0 (Van Ooijen and Voorrips, 2001) using a logarithm of the odds (LOD) threshold of 3.0 and the Kosambi mapping function (Kosambi, 1944).

\section{RESULTS}

\section{Genetic Linkage among Markers and Wsm2}

In the previous study, $\mathrm{F}_{3}$ families showed 1 (homozygous Wsm2):2 (segregating):1 (homozygous wsm2) segregation ratio $\left(\chi^{2}=1.86, p=0.39\right)$ in the CO960293-2 $\times$ TAM 111 population (Lu et al., 2011). In the CO960293-2 $\times$ Yuma population, only $106 \mathrm{~F}_{2: 3}$ families were used for disease scoring while the remaining 36 families grew poorly and the data were not usable. For $106 \mathrm{~F}_{2: 3}$ families scored for disease reaction, 30 showed a homozygous resistant reaction, 17 showed a homozygous susceptible reaction, and 59 showed a segregating reaction to WSMV infection. This segregation also fits a single gene inheritance $\left(\chi^{2}=\right.$ 4.83, $p=0.09)$ in the CO960293-2 $\times$ Yuma population.

Among the 48 markers screened for polymorphism between the parents and the bulks, five showed polymorphism between CO960293-2 and TAM 111 and also between the bulks. The five markers were then used to genotype $188 \mathrm{~F}_{2}$ individuals in the CO960293-2 × TAM 111 population. All five markers were mapped between Xgwm389 and Xgwm566, the flanking markers for Wsm2 locus. All five markers were distal to Wsm2 with XSTS55 being the closest (5.2 cM from Wsm2) (Fig. 1). In the CO960293-2 


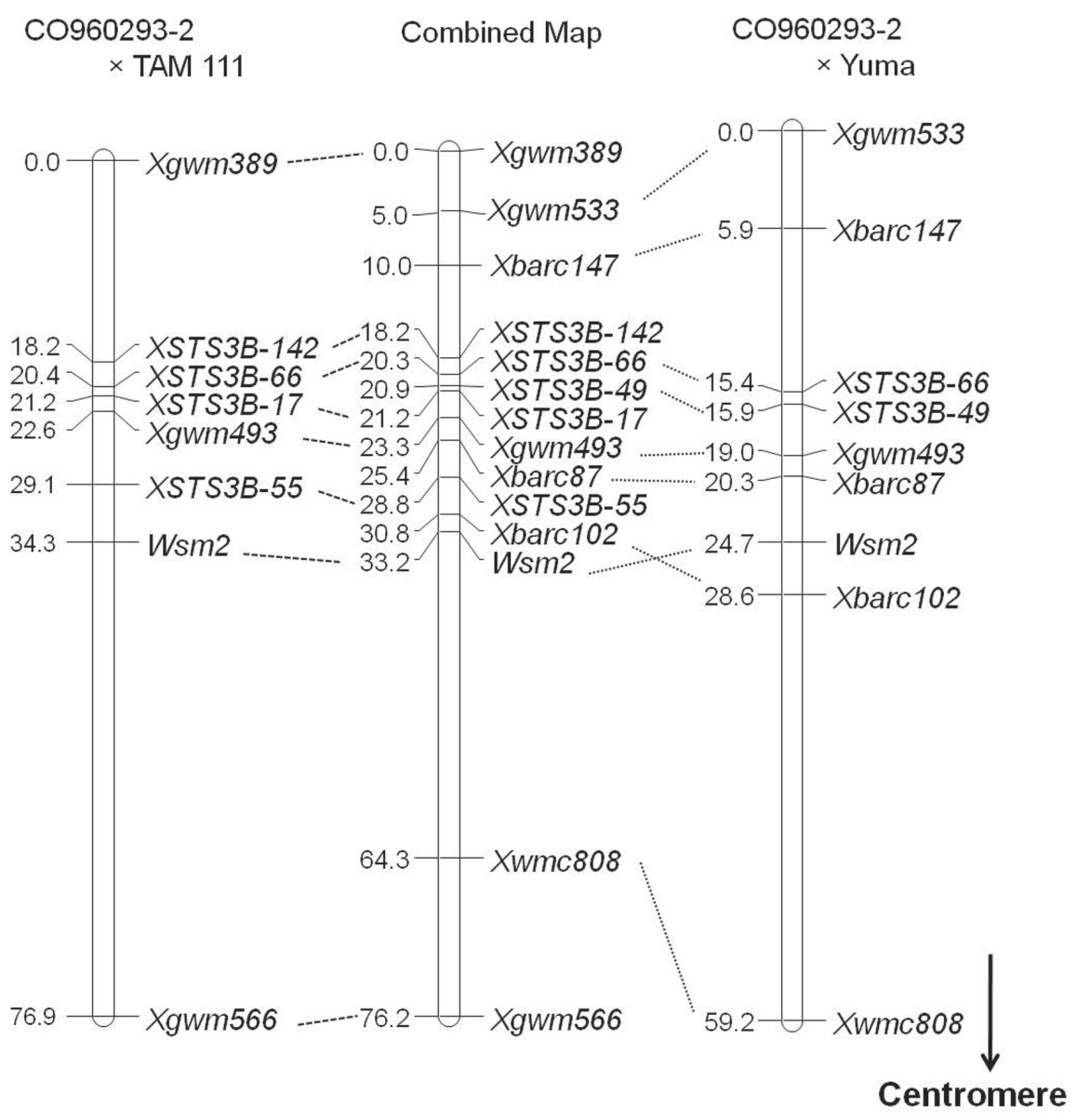

Figure 1. Genetic linkage maps constructed in wheat (Triticum aestivum L.) population CO960293-2 × TAM 111 consisting of $188 \mathrm{~F}_{2: 3}$ families and population C0960293-2 × 'Yuma' consisting of $142 \mathrm{~F}_{2: 3}$ families and the combined map. Numbers to the left of each linkage group are accumulated genetic distances in centimorgans. Markers and the gene Wsm2 are shown to the right of each linkage map.

$\times$ Yuma population, eight markers were polymorphic and were linked to Wsm2 (Fig. 1). Six markers were distal to the $W s m 2$ locus and two markers were mapped proximally to Wsm2. Thus, two new flanking markers (Xbarc102 and Xbarc87) were identified as $8.3 \mathrm{cM}$ apart. The linkage maps from the two populations had two markers (Xgwm493 and XSTS3B-66) in common. In the CO960293-2 $\times$ TAM 111 population, XSTS3B-66 was $13.9 \mathrm{cM}$ and Xgwm 493 was $11.7 \mathrm{cM}$ from Wsm2 whereas in the CO960293-2 $\times$ Yuma population, XSTS3B-66 was $9.3 \mathrm{cM}$ and Xgwm 493 was $5.7 \mathrm{cM}$ from $W_{s m 2}$. A consensus map of both populations constructed using JoinMap (Van Ooijen and Voorrips, 2001) contained 13 markers. Xwmc 808 was $31.1 \mathrm{cM}$ and Xgwm566 was $43 \mathrm{cM}$ proximal to Wsm2 whereas all other markers were distal to Wsm2 with Xbarc102 being the closest to $W s m 2(2.4 \mathrm{cM})$. In the combined map, the order of Xbarc102 and Wsm2 was swapped in comparison with the map order in the CO960293-2 $\times$ Yuma population.

\section{Validation of Markers in Different Genetic Backgrounds}

Twenty-two advanced breeding lines developed by the wheat breeding programs at Agricultural Research Center, Kansas State University, Hays, KS, and at Colorado State
University, Fort Collins, CO, were tested for their responses to WSMV infection. CO960-293-2 or RonL were ancestors in the pedigrees of these lines. Eighteen lines were resistant and four were susceptible. As expected, Wsm2carrying genotypes CO960293-2, CO960293-w133, and Snowmass and Wsm1-carrying genotype KS96HW10-3 were resistant to WSMV while Karl 92, N96L9970, and TAM 107 were susceptible to WSMV (Table 1).

Four codominant markers were screened in the 22 advanced breeding lines. CO960293-2 had a 219-bp fragment at Xbarc102, a 202-bp fragment at XSTS3B-55, a 119-bp fragment at Xbarc87, and a 214-bp fragment at Xgwm493. The 219-bp fragment of Xbarc102 was present in all resistant accessions except KS96HW10-3, in which Wsm1 is responsible for the resistance (Fig. 2). All susceptible advanced breeding lines and controls lacked the 219-bp fragment of Xbarc102 (Table 1). Therefore, Xbarc102-219-bp cosegregated with Wsm2 among these accessions. Xbarc 87 correctly predicted presence or absence of $W_{s m} 2$ in 22 of 25 genotypes tested (88\%) including 22 breeding lines, CO960293-2, CO960293-w133, and Snowmass. The 119-bp allele of Xbarc87 was also present in KS97HW10-3 (Wsm1) and Karl 92 but not in N96L9970 or TAM 107. A similar result as Xbarc87 was obtained for Xgwm493 


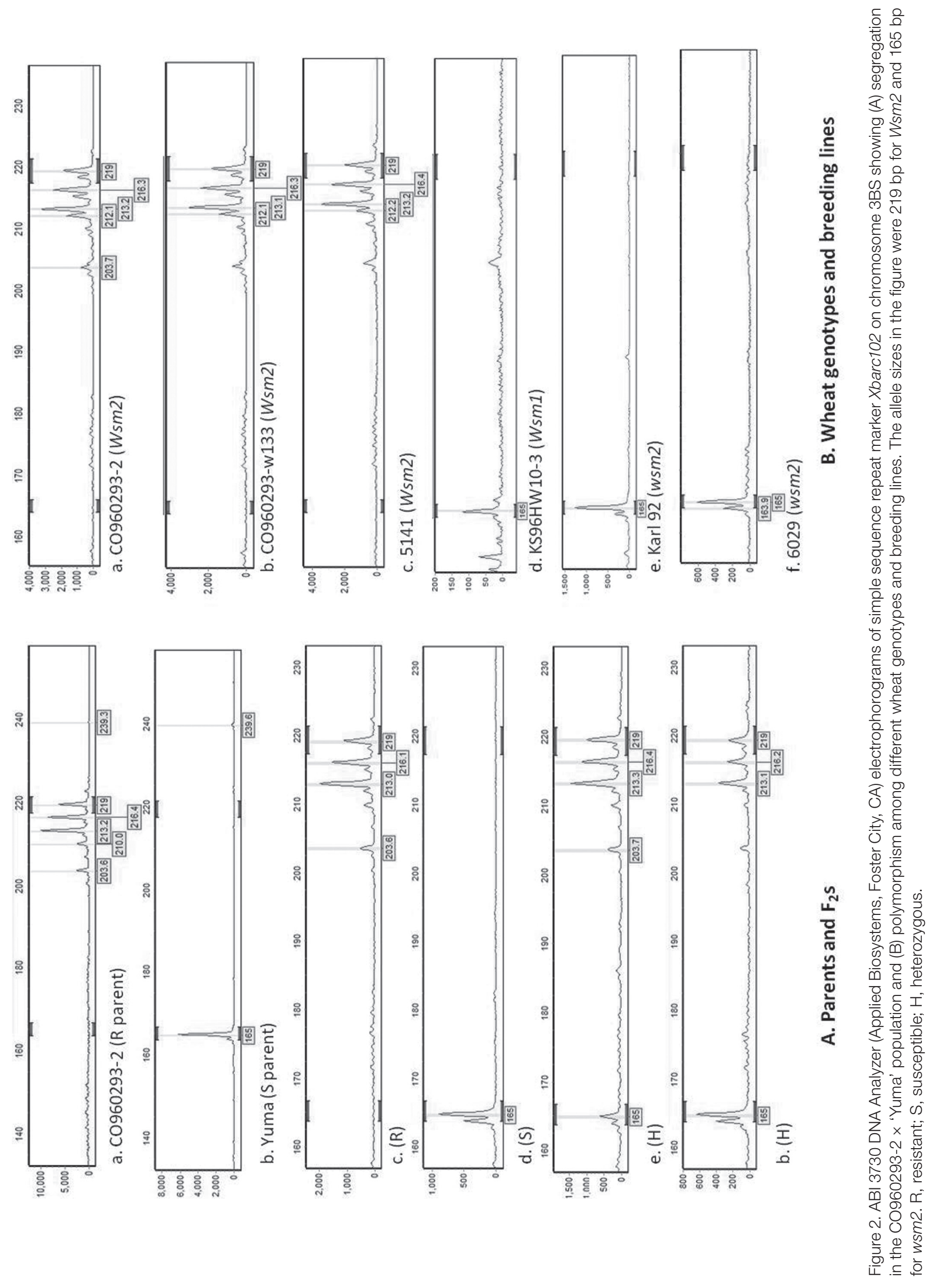


except that the 214-bp fragment of Xgwm493 was absent in KS96HW10-3, Karl 92, and CO960293-w133. Although RonL was not included in the marker validation experiment, it amplified the marker alleles Xbarc102-219-bp, Xbarc87-119-bp, and Xgwm493-214-bp in a separate PCR run. Primer STS3B-55 for XSTS3B-55 failed to amplify the targeted fragment in these accessions and was therefore excluded from further analysis.

\section{DISCUSSION}

CO960293-2 was a selection from the cross PI 222668/ TAM 107//CO850034 and released as a germplasm source for resistance to Russian wheat aphid (Diuraphis noxia Kurdjumov) and WSMV (Haley et al., 2002). Russian wheat aphid resistance was presumably inherited from PI 222668 but the origin of the WSMV resistance is unknown since none of the parents of CO960293-2 are known to have resistance to WSMV (Haley et al., 2002). Some early preliminary studies showed that WSMV resistance in CO960293-2 might be controlled by a different gene than Wsm1 (Haley et al., 2002; Seifers et al., 2006). Initial genetic study of resistance using the CO960293-2 × TAM 111 population confirmed this assumption and found that the WSMV resistance was conditioned by a dominant gene on wheat chromosome 3BS designated as $W_{s m} 2$ (Lu et al., 2011). In this study, the segregation ratio of resistance to susceptibility in the CO960293-2 $\times$ Yuma population also supported the previous results and confirms that Wsm2 is responsible for resistance in CO960293-2.

In the previous map, Wsm2 was flanked by two remote SSR markers Xgwm 389 and Xgwm566 at an interval of $76.2 \mathrm{cM}$ (Lu et al., 2011). Here, we added 11 more markers to the linkage group (Fig. 1). Although the markers Xgwm533, Xbarc147, and Xwmc808 were mapped at genetic distances greater than $20 \mathrm{cM}$ from $W s m 2$ in the CO960293-2 $\times$ Yuma population and also in the combined linkage map, most of the markers identified in this study were close to Wsm2. The closest marker to Wsm2 was Xbarc102, which was mapped proximally to Wsm2 at $3.9 \mathrm{cM}$ in the CO960293-2 $\times$ Yuma population but placed $2.4 \mathrm{cM}$ distally to $W_{s m} 2$ in the consensus map. The discrepancy in marker order between the two maps may have been caused by the populations used and the position of crossovers along chromosomes within the progeny lines as explained in Somers et al. (2004). Nevertheless, the order change between Wsm2 and Xbarc102 in different maps should not adversely affect the application of the marker in MAS.

The marker order, Xgwm493-Xbarc87-XSTS-3B55Xbarc102, in the consensus map is in agreement with that of Liu and Anderson (2003) except that in the latter XSTS3B-55 and Xbarc102 cosegregated. Based on the consensus map of Somers et al. (2004), Xgwm493 and Xbarc87, which have the same order as in the present study, are located in the distal $30 \%$ portion of the short arm of chromosome 3B. Therefore, Wsm2 is in the distal 30\% portion of 3BS shown in the map of Somers et al. (2004).

In addition to $W_{s m} 2$, chromosome $3 \mathrm{BS}$ harbors some important disease resistance genes such as the durable stem rust (Puccinia graminis f. sp. Tritici) gene Sr2 and the Fusarium head blight (FHB) (Fusarium graminearum) resistance quantitative trait loci (QTL) Fhb1. Sr2 was originally identified in cultivar Hope (CItr 8178; Hare and McIntosh, 1979) and was later mapped to the interval of Xgwm389 and Xgwm533 on 3BS (Spielmeyer et al., 2003). Fhb1 is present in the Chinese cultivar Sumai 3 (PI 481542) and is a major QTL for FHB resistance. Using the recombinant inbred lines (RILs) derived from the cross of Sumai $3 \times$ 'Stoa', Liu and Anderson (2003) found that the peak of LOD plots for FHB resistance was near the cosegregating markers XSTS3B-138 and XSTS3B-52. In their map, XSTS3B-138 and XSTS3B-52 were proximal to Xgwm389 and Xgwm533 but distal to XSTS3B-55 and Xbarc102 (Liu and Anderson, 2003). These comparisons of map positions among the markers and genes suggest that Fhb1 is proximal to the $S r 2$ locus and the Wsm2 locus is proximal to the Fhb1 locus, giving a relative map order of Sr2- Fhb1-Wsm2-centromere. Therefore, it should be possible to pyramid the three genes into a single cultivar providing multiple diseases resistance. This would be highly desirable since stem rust, FHB, and wheat streak mosaic (WSM) may occur in the same wheat growing season in the Great Plains of North America.

Usefulness of a marker in MAS is dependent on the polymorphism level and genetic distance between the marker and the gene of interest. Markers tightly linked to target genes and having sufficient polymorphism have been identified and used for MAS in wheat. Examples include markers for the stem rust resistance gene $\mathrm{Sr} 2(\mathrm{McNeil}$ et al., 2008), leaf rust (Puccinia triticina Eriks.) resistance gene Lr42 (Sun et al., 2010), Hessian fly (Mayetiola destructor Say) resistance gene H32 (Yu et al., 2010), and the tan spot [Pyrenophora tritici-repentis (Died.) Drechs.] susceptibility gene Tsn1 (Lu et al., 2006). In this study, three of the four tested markers predicted presence or absence of Wsm 2 in advanced breeding lines at $88 \%$ or higher accuracies. The marker allele Xbarc102-219-bp was the best predictor for $W_{s m} 2$ with 100\% accuracy. Furthermore, the 219-bp fragment was present in CO960293-2, CO960293-w133, Snowmass, and RonL but absent in KS96HW10-3, Karl 92, N96L9970, and TAM 107 indicating that polymorphism for Xbarc102 exists in different germplasm lines. Marker XSTS3B-55 was mapped $5.2 \mathrm{cM}$ distal to $W_{s m 2}$ in the CO960293-2 $\times$ TAM 111 population. However, the primer STS3B-55 failed to amplify the targeted 202bp fragment in our MAS test. This inconsistency indicates that STS3B-55 may require optimized PCR conditions for reliable use. 


\section{CONCLUSIONS}

Genetic analysis in two segregating populations confirmed previous studies indicating that WSMV resistance in hard winter wheat line CO960293-2 is controlled by a single dominant gene Wsm2. Wsm2 is located in the distal 30\% portion of wheat chromosome 3BS. Of the 13 molecular markers mapped in the $W_{s} m 2$ region in two populations, Xbarc102 and XSTS3B-55 are the closest makers to Wsm2. In this study, Xbarc102 predicted the presence of Wsm2 at $100 \%$ accuracy among a collection of advanced breeding lines. Wsm2 has been deployed in the recently released cultivars RonL and Snowmass to protect wheat crops from damage by Wheat streak mosaic virus. The markers closely linked to Wsm2 identified in this study will help wheat breeders to accelerate the breeding process of transferring $W s m 2$ to adapted cultivars.

\section{Supplemental Information Available}

Supplemental material is available at http://www.crops. org/publications/cs.

\section{Acknowledgments}

This research was supported by the grants from the Texas Wheat Producers Board, Texas AgriLife Research Monocot Improvement Program, the Colorado Wheat Administrative Committee, the Colorado Wheat Research Foundation, and the National Research Initiative of USDA's Cooperative State Research, Education and Extension Service, CAP grant number 2006-55606-16629.

\section{References}

Baley, G.J., L.E. Talbert, J.M. Martin, M.J. Young, D.K. Habernicht, G.D. Kushnak, J.E. Berg, S.P. Lanning, and P.L. Bruckner. 2001. Agronomic and end-use qualities of wheat streak mosaic virus resistant spring wheat. Crop Sci. 41:1779-1784.

Christian, M.L., and W.G. Willis. 1993. Survival of wheat streak mosaic virus in grass hosts in Kansas from wheat harvest to fall wheat emergence. Plant Dis. 77:239-242.

French, R., and D.C. Stenger. 2003. Evolution of wheat streak mosaic virus: Dynamics of population growth within plants may explain limited variation. Annu. Rev. Phytopathol. 41:199-214.

Friebe, B., Y. Mukai, H.S. Dhaliwal, T.J. Martin, and B.S. Gill. 1991. Identification of alien chromatin specifying resistance to wheat streak mosaic and greenbug in wheat germplasm by C-banding and in situ hybridization. Theor. Appl. Genet. 81:381-389.

Friebe, B., L.L. Qi, D.L. Wilson, Z.J. Chang, D.L. Seifers, T.J. Martin, A.K. Fritz, and B.S. Gill. 2009. Wheat-Thinopyrum intermedium recombinants resistant to Wheat streak mosaic virus and Triticum mosaic virus. Crop Sci. 49:1221-1226.

Graybosch, R.A., C.J. Peterson, P.S. Baenziger, D.D. Baltensperger, L.A. Nelson, Y. Jin, J. Kolmer, B. Seabourn, R. French, G. Hein, T.J. Martin, B. Beecher, T. Schwarzacher, and P. Heslop-Harrison. 2009. Registration of 'Mace' hard red winter wheat. J. Plant Reg. 3:51-56.

Graybosch, R.A., C.J. Peterson, D.R. Porter, and O.K. Chung.
2004. Registration of N96L9970 greenbug resistant wheat. Crop Sci. 44:1492-1493.

Haley, S.D., J.J. Johnson, F.B. Peairs, J.A. Stromberger, E.E. Heaton, S.A. Seifert, R.A. Kottke, J.B. Rudolph, G. Bai, R.L. Bowden, M.-S. Chen, X. Chen, Y. Jin, J.A. Kolmer, and B.W. Seabourn. 2011. Registration of 'Snowmass' wheat. J. Plant Reg. 5:1-4.

Haley, S.D., T.J. Martin, J.S. Quick, D.L. Seifers, J.A. Stromberger, S.R. Clayshulte, B.L. Clifford, F.B. Peairs, J.B. Rudolph, J.J. Johnson, B.S. Gill, and B. Friebe. 2002. Registration of CO960293-2 wheat germplasm resistant to wheat streak mosaic virus and Russian wheat aphid. Crop Sci. 42:1381-1382.

Haley, S., J. Quick, J. Johnson, F. Peairs, J. Stromberger, S. Clayshulte, B. Clifford, J. Rudolph, and O. Chung. 2004. Registration of 'Ankor' wheat. Crop Sci. 44:1025-1026.

Hare, R.A., and R.A. McIntosh. 1979. Genetic and cytogenetic studies of durable, adult-plant resistance in Hope and related cultivars to rusts. Z. Pflanzen 83:350-367.

Kosambi, D.D. 1944. The estimation of map distances from recombination values. Ann. Eugen. 12:172-175.

Lazar, M.D., W.D. Worrall, G.L. Peterson, A.K. Fritz, D. Marshall, L.R. Nelson, and L.W. Rooney. 2004. Registration of 'TAM 111' wheat. Crop Sci. 44:353-355.

Liu, S., and J. Anderson. 2003. Targeted molecular mapping of a major wheat QTL for Fusarium head blight resistance using wheat ESTs and synteny with rice. Genome 46:817-823.

Lu, H., J.P. Fellers, T.L. Friesen, S.W. Meinhardt, and J.D. Faris. 2006. Genomic analysis and marker development for the Tsn1 locus in wheat using bin-mapped ESTs and flanking BAC contigs. Theor. Appl. Genet. 112:1132-1142.

Lu, H., J. Price, R. Devkota, C. Rush, and J. Rudd. 2011. A dominant gene for resistance to wheat streak mosaic virus in winter wheat line CO960293-2. Crop Sci. 51:5-12.

McNeil, M.D., R. Kota, E. Paux, D. Dunn, R. McLean, C. Feuillet, D. Li, X. Kong, E. Lagudah, J.C. Zhang, J.Z. Jia, W. Spielmeyer, M. Bellgard, and R. Appels. 2008. BAC-derived markers for assaying the stem rust resistance gene, $\mathrm{Sr} 2$, in wheat breeding programs. Mol. Breed. 22:15-24.

Michelmore, R.W., I. Paran, and R.V. Kesseli. 1991. Identification of markers linked to disease resistance genes by bulked segregant analysis: A rapid method to detect markers in specific genomic regions by using segregating populations. Proc. Natl. Acad. Sci. USA 88:9828-9832.

Porter, K.B., W.D. Worrall, J.H. Gardenhire, E.C. Gilmore, M.E. McDaniel, and N.A. Tuleen. 1987. Registration of 'TAM 107' wheat. Crop Sci. 27:818.

Sears, R.G., T.J. Martin, T.S. Cox, O.K. Chung, S.P. Curran, W.F. Heer, and M.D. Witt. 1997. Registration of 'Karl 92' wheat. Crop Sci. 37:628.

Seifers, D.L. 1992. Partial characterization of a Colorado isolate of Agropyron mosaic virus. Plant Dis. 76:564-569.

Seifers, D.L., R.C. French, D.C. Stenger, and T.J. Martin. 2003. Biological variation among wheat streak mosaic virus isolates. American Phytopathological Society Annual Meeting. Phytopathology 93(supplement):S78.

Seifers, D.L., T.J. Martin, T.L. Harvey, J.P. Fellers, J.P. Stack, M. Ryba-White, S. Haber, O. Krokhin, V. Spicer, N. Lovat, A. Yamchuk, and K.G. Standing. 2008. Triticum mosaic virus: A new virus isolated from wheat in Kansas. Plant Dis. 92:808-817.

Seifers, D.L., T.J. Martin, T.L. Harvey, and B.S. Gill. 1995. Temperature-sensitivity and efficacy of wheat streak mosaic virus resistance derived from Agropyron intermedium. Plant Dis. 
79:1104-1106.

Seifers, D.L., T.J. Martin, T.L. Harvey, and S. Haber. 2007. Temperature-sensitive wheat streak mosaic virus resistance identified in KS03HW12 wheat. Plant Dis. 91:1029-1033.

Seifers, D.L., T.J. Martin, T.L. Harvey, S. Haber, and S.D. Haley. 2006. Temperature sensitivity and efficacy of wheat streak mosaic virus resistance derived from CO960293-2 wheat. Plant Dis. 90:623-628.

Sharp, G.L., J.M. Martin, S.P. Lanning, N.K. Blake, C.W. Brey, E. Sivamani, R. Qu, and L.E. Talbert. 2002. Field evaluation of transgenic and classical sources of wheat streak mosaic virus resistance. Crop Sci. 42:105-110.

Somers, D.J., P. Isaac, and K. Edwards. 2004. A high-density microsatellite consensus map for bread wheat (Triticum aestivum L.). Theor. Appl. Genet. 109:1105-1114.

SoftGenetics. 2010. GeneMarker version 1.6. SoftGenetics LLC, State College, PA.

Spielmeyer, W., P.J. Sharp, and E.S. Lagudah. 2003. Identification and validation of markers linked to broad-spectrum stem rust resistance gene $\mathrm{Sr} 2$ in wheat (Triticum aestivum L.). Crop Sci. 43:333-336.
Sun, X., G. Bai, B.F. Carver, and R. Bowden. 2010. Molecular mapping of wheat leaf rust resistance gene Lr42. Crop Sci. 50:59-66.

USDA Agricultural Research Service (USDA-ARS). 2010. GrainGenes: A database for Triticeae and Avena. Available at http:// wheat.pw.usda.gov/GG2/index.shtml (verified 16 Nov. 2011). USDA-ARS, Washington, DC.

Van Ooijen, J.W., and R.E. Voorrips. 2001. JoinMap 3.0. SoftGenetics LLC, PRI, Wageningen, the Netherlands.

Wells, D.G., R.S. Kota, H.S. Sandhu, W.S. Gardner, and K.F. Finney. 1982. Registration of one disomic substitution line and five translocation lines of winter wheat germplasm resistant to wheat streak mosaic virus. Crop Sci. 22:1277-1278.

Wells, D.G., R. Wong, S. Chung, C.L. Lay, W.S. Gardner, and G.W. Buchenau. 1973. Registration of C.I. 15092 and C.I. 15093 wheat germplasm. Crop Sci. 13:776.

Yu, G., C.E. Williams, M.O. Harris, X. Cai, M. Mergoum, and S.S. Xu. 2010. Development and validation of molecular markers closely linked to $H 32$ for resistance to Hessian fly in wheat. Crop Sci. 50:1325-1332. 